\title{
Genetic Analysis of Two Sympatric Sea Urchins from Genus Diadema (Echinodermata: Echinoidea: Diadematidae) from Malaysian Borneo
}

\author{
NURSYUHAIDA MD SHAHID*, RAYMIE NURHASSAN, SITI AKMAR KHADIJAH AB \\ RAHIM \& RUHANA HASSAN
}

\author{
Department of Aquatic Science, Faculty of Resource Science and Technology, Universiti Malaysia \\ Sarawak, 94300 Kota Samarahan, Sarawak, Malaysia
}

\begin{abstract}
Genus Diadema (Echinoidea: Diadematidae) has been reported to be the most widespread and ecologically important shallow water tropical sea urchins. Morphological variations and species distributions are complicated to elucidate due to complexity in making reliable identifications. Genus Diadema had involved in many debates, particularly on the mode of speciation and the specific status of Diadema setosum and Diadema savignyi. Therefore, relationships among Diadema species found in Malaysian Borneo have been examined using 16S rRNA gene analysis. Monophyletic clade of genus Diadema with respect to the outgroup was obtained with high bootstrap values of $100 \%(\mathrm{MP}), 100 \%$ (NJ), 100\% (ML) and Bayesian Posterior Probability is equal to 1.00 . Two monophyletic clades were apparent separating D. setosum (Clade I) and D. savignyi (Clade II), with strong support of $100 \%$ (MP), $100 \%$ (NJ), $80 \%$ (ML) and Bayesian Posterior Probability is equal to 1.00 . In addition, high genetic variation among species had been recorded (9.85\%), suggesting that D. setosum and D. savignyi are two distinct entities. Furthermore, D. setosum and D. savignyi are sympatric species based on their distribution and overlapping ranges in Malaysian Borneo.
\end{abstract}

Keywords: Diadema, sympatric species, phylogenetic, 16S rRNA gene

\section{INTRODUCTION}

Genus Diadema had been reported to be the most widespread and ecologically important shallow water genera of tropical sea urchins (Lessios, 2001) by controlling the population of algae and maintaining the balance of food chain relationship. Distinctions in their distributions among species of genus Diadema, are complicated to elucidate due to complexity in making reliable identifications (Pearse, 1998). Their systematics and biogeography are enmeshed in uncertainty until study conducted by Mortensen (1940) appeared to stabilize the systematics of Diadema. There are eight species in genus Diadema: Diadema-sp, $D$. mexicanum, D. antillarum, D. ascensionis, D. palmeri, D. paucispinum, D. setosum and D. savignyi (Lessios, 2001). However, only two species D. setosum and D. savignyi (Figure 1) could be found in Malaysian Borneo (Rahim \& Nurhassan, 2012).

D. setosum Leske 1778 , is a long spine black sea urchin characterized by the unique morphology of orange anal ring, green bands of iridophores down the midlines of interambulacra and five blue or white spots on the anal tube (Coppard \& Campbell, 2006). This species possesses three to five tubercles along the inner edge of the genital plates and at larval stage, it has several long arms to funnel food particles and facilitate their movement (Yokota et al., 2002).

On the other hand, D. savignyi Michelin 1845 is known as a black sea urchin, has shorter spine compared to D. setosum with bold pattern of iridophores on the aboral surface forming connecting lines rather than spots. It possesses black anal tube, distinct arch-shaped depression on the genital plate in adult form and the black test was distinctively horizontally circular with white line radiated out from the genital plates down the midlines of inter ambulacra (Coppard \& Campbell, 2006). The naked median areas can be observed with small red or brown spot during the day and the spots will be seen larger in size at night as the chromatophores retracted and revealed the test (Coppard \& Campbell, 2006).

*Corresponding author: syuhaidashahid@gmail.com 

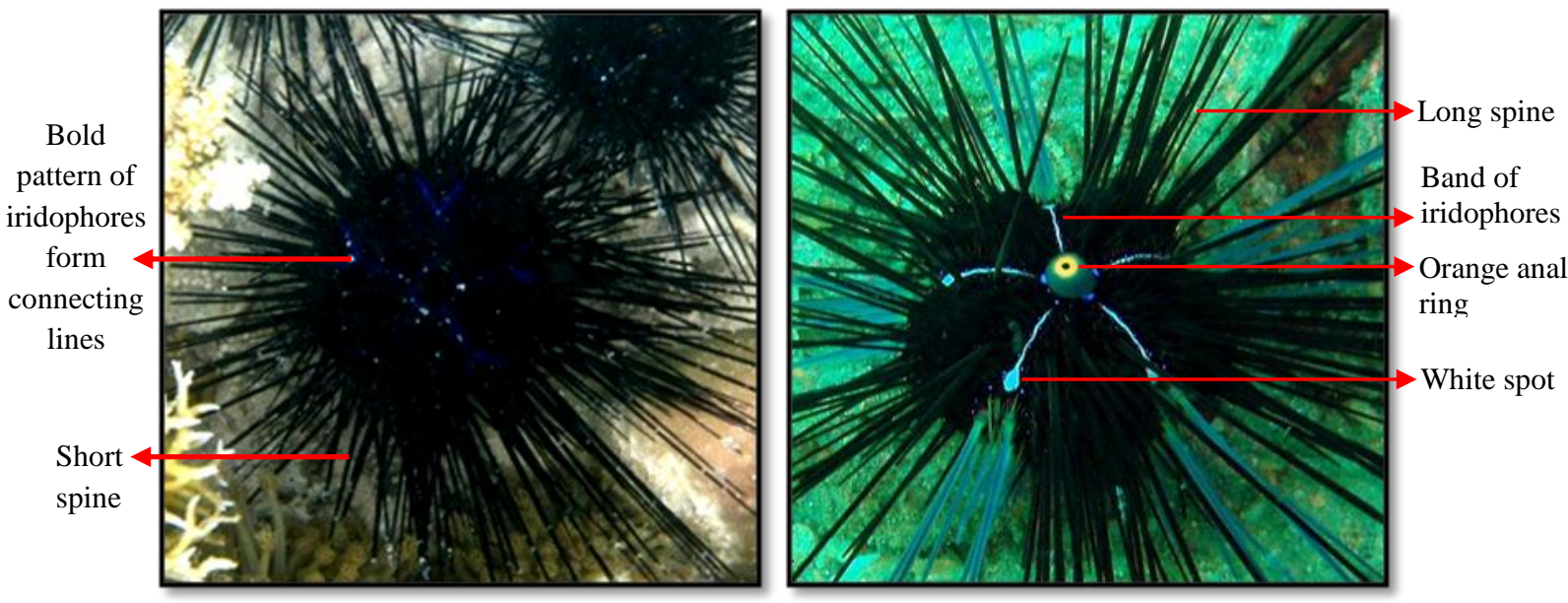

Figure 1. Photographs showing morphological characteristics of D. savignyi (left) and D. setosum (right).

According to Lessios et al. (2001), one of the earliest study on species distributions of tropical sea urchin was conducted by Mayr (1954) in which the study found that the model of speciation for sea urchin was allopatric due to the distribution of the organisms on either side of a land or the open sea barrier. However, problem arise as to determine the model of speciation in genus Diadema as two morphologically similar species namely $D$. setosum and $D$. savignyi with overlapping ranges in the Indo-Pacific were thought to be identical and that the two species were speculated to be the result of 'double invasion' in the Indo West Pacific (Lessios et al., 2001).

There has been great confusion regarding the specific status and geographical distributions of D. setosum and D. savignyi. Debates on either they are sympatric species have been discussed by many researchers for example hypothesis on overlapping populations (Mortenson, 1940; Mayr, 1954), distribution pattern in the wide ocean (Pearse, 1998; Lessios, 2001), morphological similarities (Clark, 1966; Coppard \& Campbell, 2006), theories on natural hybrids (Lessios \& Pearse, 1996) and annual rhythm of active spawning (Adel \& Khalid, 2000). Thus, phylogenetic study was suggested to reveal whether the two morphologically similar urchins have distinct genetic identity.

At the very beginning of this study, hypothesis null stated that both $D$. setosum and D. savignyi have the same genetic composition and could be a subspecies. Whereas hypothesis alternative is $D$. setosum and $D$. savignyi have substantial genetic variation and are reciprocally monophyletic. In the study, $16 \mathrm{~S}$ rRNA gene information was utilized as the molecular marker to illustrate phylogenetic relationships and the specific status of genus Diadema in Malaysian Borneo involving two species, D. setosum and D. savignyi.

\section{MATERIALS \& METHODS}

A total of 20 samples consisted of eight samples of D.setosum, three samples of $D$. savignyi, five samples of E. calamaris and four samples of $T$. gratilla were collected from various locations in Malaysian Borneo (Figure 2; Table 1). Altogether, two species from genus Diadema were found in Malaysian Borneo with $E$. calamaris, member of family Diadematidae and one species from family Toxopneustidae were used as the outgroups.

The specimens were collected using SCUBA diving, snorkeling or manual collection depending on the tide level and beach profile involved (Figure 2). An amount of $1 \mathrm{~g}$ of soft tissues from the lateral line inside the carapace (red to brown in color) have been collected using sterile scalpel blade and placed into labeled tubes based on localities. The tissue samples were preserved in 70\% ethanol and 5\% EDTA, later kept in Aquatic Molecular Laboratory, Faculty of Resource Science and Technology, Universiti Malaysia Sarawak during this study. 


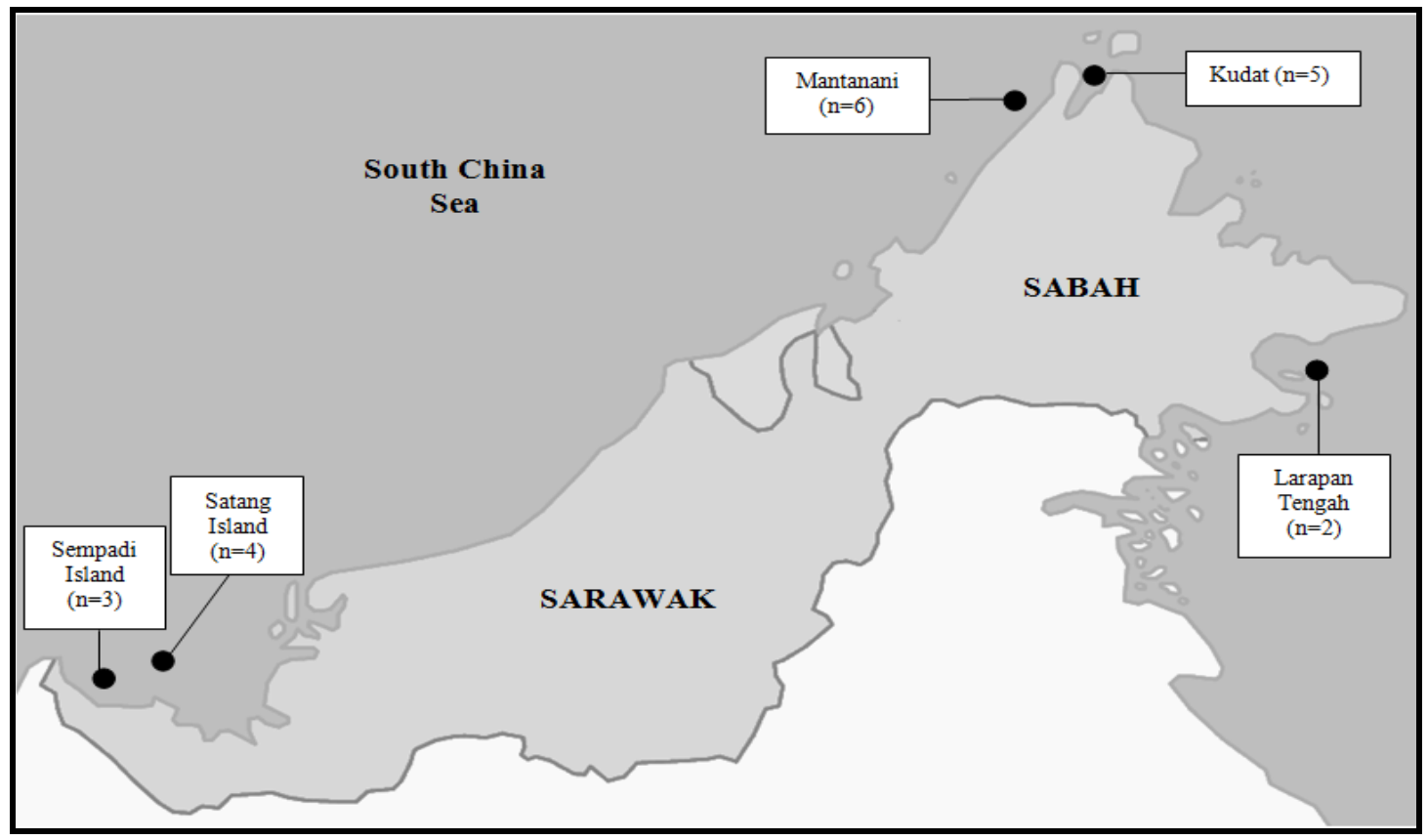

Figure 2. Map of Malaysian Borneo showing study locations and sample size (n) of the sea urchins collected for this study.

Table 1. Samples of D. setosum, D. savignyi, E. calamaris and T. gratilla analysed for 16S rRNA gene sequences variation with locality, GPS reading and field voucher.

\begin{tabular}{|c|c|c|c|c|}
\hline Species & Locality & GPS reading & $\begin{array}{c}\text { Field } \\
\text { voucher }\end{array}$ & $\begin{array}{c}\text { Accession } \\
\text { number }\end{array}$ \\
\hline D. setosum & Satang Island, Sarawak & 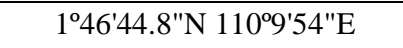 & STG02B & KJ874195 \\
\hline D. setosum & Satang Island, Sarawak & $1^{\circ} 46^{\prime} 44.8^{\prime \prime} \mathrm{N} 110^{\circ} 9^{\prime} 54^{\prime \prime E}$ & STG07B & KJ874199 \\
\hline D. setosum & Kudat, Sabah & $6^{\circ} 56^{\prime} 684^{\prime \prime N} 116^{\circ} 50^{\prime} 387^{\prime \prime E}$ & K08 & KJ874192 \\
\hline D. setosum & Larapan Tengah, Sabah & 4³3'275"N 118³6'696"E & LT07 & KJ874185 \\
\hline D. setosum & Larapan Tengah, Sabah & 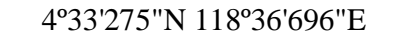 & LT08 & KJ874186 \\
\hline D. setosum & Mantanani Island, Sabah & $6^{\circ} 42.8^{\prime} \mathrm{N} 116^{\circ} 18.3^{\prime} \mathrm{E}$ & M06 & KJ857078 \\
\hline D. setosum & Mantanani Island, Sabah & $6^{\circ} 42.8^{\prime} \mathrm{N} 116^{\circ} 18.3^{\prime} \mathrm{E}$ & M07 & KJ857079 \\
\hline D. setosum & Mantanani Island, Sabah & $6^{\circ} 42.8^{\prime} \mathrm{N} 116^{\circ} 18.3^{\prime} \mathrm{E}$ & M10 & KJ857082 \\
\hline D. savignyi & Mantanani Island, Sabah & $6^{\circ} 42.8^{\prime} \mathrm{N} 116^{\circ} 18.3^{\prime} \mathrm{E}$ & SV01 & KJ908847 \\
\hline D. savignyi & Mantanani Island, Sabah & $6^{\circ} 42.8^{\prime} \mathrm{N} 116^{\circ} 18.3^{\prime} \mathrm{E}$ & SV03 & KJ908848 \\
\hline D. savignyi & Mantanani Island, Sabah & $6^{\circ} 42.8^{\prime} \mathrm{N} 116^{\circ} 18.3^{\prime} \mathrm{E}$ & SV04 & KJ908849 \\
\hline E. calamaris & Satang Island, Sarawak & 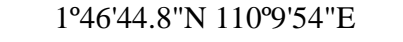 & TG01 & KJ908852 \\
\hline E. calamaris & Satang Island, Sarawak & $1^{\circ} 46^{\prime} 44.8^{\prime \prime N} 110^{\circ} 9^{\prime} 54^{\prime \prime} \mathrm{E}$ & TG02 & KJ908853 \\
\hline E. calamaris & Sampadi Island, Sarawak & 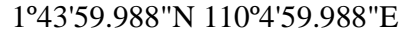 & TG03 & KJ908854 \\
\hline E. calamaris & Sampadi Island, Sarawak & $1^{\circ} 43^{\prime} 59.988^{\prime \prime} \mathrm{N} 110^{\circ} 4^{\prime} 59.988^{\prime E}$ & TG04 & KJ908855 \\
\hline E.calamaris & Sampadi Island, Sarawak & 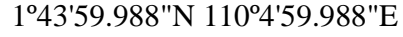 & TG05 & KJ908856 \\
\hline T. gratilla & Kudat, Sabah & 656'684"N 11650'387"E & GR01 & KJ908857 \\
\hline T. gratilla & Kudat, Sabah & 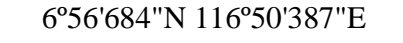 & GR05 & KJ908858 \\
\hline T. gratilla & Kudat, Sabah & $6^{\circ} 56^{\prime} 684^{\prime \prime N} 116^{\circ} 50^{\prime} 387^{\prime \prime E}$ & GR06 & KJ908859 \\
\hline T. gratilla & Kudat, Sabah & $6^{\circ} 56^{\prime} 684^{\prime \prime N} 116^{\circ} 50^{\prime} 387^{\prime \prime E}$ & GR10 & KJ908860 \\
\hline
\end{tabular}

Total genomic DNA extraction was conducted using modified CTAB protocol (Doyle and Doyle, 1987) with addition of Proteinase-K. Optical Density reading at $260 \mathrm{~nm}$ and $280 \mathrm{~nm}$ were conducted using UV spectrophotometer model Ultraspec ${ }^{\circledR} 100$ Pro. Amplification of approximately 600 base pair of $16 \mathrm{~S}$ rRNA gene used a pair of primers, 16SAR forward primer (5'- CGC CTG TTT ATC AAA AAC AT-3') and 16SBR reverse primer (5'- CCG GTC TGA ACT CAG ATC ACG -3') designed by Palumbi (1996). PCR was performed in a total reaction volume of $25 \mu \mathrm{l}$ containing $100 \mathrm{ng}$ of DNA template, 5X PCR buffer, $25 \mathrm{mM}$ of $\mathrm{MgCl}, 10$ 
$\mathrm{mM}$ of deoxynucleotide triphosphate (dNTP), $0.2 \mu \mathrm{M}$ of primer and $5 \mathrm{u} / \mu \mathrm{l}$ Taq DNA polymerase. PCR thermal cycling profile for amplification of $18 \mathrm{~S}$ rRNA gene started with pre-denaturation temperature of $95^{\circ} \mathrm{C}$ for 2 minutes, followed by 30 cycles of denaturation at $94^{\circ} \mathrm{C}$ for 30 seconds, $55^{\circ} \mathrm{C}$ annealing temperature for 30 seconds, and extension temperature of $72^{\circ} \mathrm{C}$ for 30 seconds, and a final extension at $72^{\circ} \mathrm{C}$ for 2 minutes.

All DNA extraction products and PCR products were later subjected to $1 \%$ agarose gel electrophoresis (AGE). The amplification products were purified using DNA purification kit (Vivantis, Kuala Lumpur, FT, Malaysia) according to the manufacturer's instructions. Then, the purified PCR products were sent to FirstBASE Sdn.Bhd. (Selangor) for the sequencing of forward and reverse strands.

Multiple sequence alignments were carried out via CLUSTALX program (vers. 1.81, Thompson et al., 1997). The aligned data were then transformed into a distance matrix using Kimura's Two Parameter Model (Kimura, 1980). Maximum likelihood (ML) was conducted based on the substitution model of Akaike information criterion $(\mathrm{TrN}+\mathrm{G})$ as selected by Modeltest 3.7 (Posada and Crandall, 1998). Confidence level of the NeighborJoining (NJ), Maximum Parsimony (MP) and ML were assessed using PAUP version $4.0 \mathrm{~b} 10$ (Swofford, 2000), with only bootstrap values more than $80 \%$ were shown and regarded as sufficiently resolved topologies as Heulsenback and Hillis (1993) stated that only bootstrap values of $70 \%$ or greater indicate sufficiently resolved topologies. Bayesian approach (BA) was conducted in MrBayes version 3.1.2 (Ronquist \& Huelsenback, 2003) using the same model of evolution $(\operatorname{TrN}+\mathrm{G})$ with two simultaneous metropolis-coupled Monte-Carlo Markov chains that were run for 110000 generations. A tree was sampled every 100 generations and a consensus topology was calculated for 825 trees by omitting the first 275 trees as burn-in and the confidence level of tree nodes was indicated by posterior probabilities which they represented the true probabilities of the clades (Rannala \& Young, 1996) and that probability equal or greater than $95 \%$ were considered significant (Leache \& Reeder, 2002).
All sequences of $D$. setosum obtained were deposited in the Genbank with accession number of KJ874185 to KJ857082, sequences of $D$. savignyi can be obtained by the accession number of KJ908847 to KJ908849, sequences of Echinothrix calamaris can be obtained by the accession number KJ908852 to KJ908856 while sequences of Tripneustes gratilla can be obtained by the accession number of KJ908857 to KJ908860.

\section{RESULTS \& DISCUSSION}

Out of the $542 \mathrm{bp}$ of 16S rRNA gene obtained from $D$. setosum and $D$. savignyi samples, a total amount of 56 variables sites have been observed with 5 singleton sites and 51 (91\%) parsimonious informative sites which indicates that $16 \mathrm{~S}$ rRNA gene is a reliable marker to infer genetic variation and phylogenetic relationship among Diadema species. Genetic divergence analysis of Diadema species showed more than $30 \%$ genetic distance value with respect to the outgroup $T$. gratilla (Table 2 ), indicate specific recognition as the outgroup belongs to family Toxopneustidae while $D$. setosum and $D$. savignyi belong to family Diadematidae. This finding is congruent with the study conducted on echinoderm by McCartney et al. (2000), Sponer et al. (2001) and Stockley et al. (2005) in which more than $30 \%$ genetic distance value was recorded between ingroup and outgroup taxa using 16S rRNA gene analysis.

Moreover, genetic divergence analysis revealed genetic distance value of more than $13 \%$ recorded between species of Diadema and the outgroup, E. calamaris (Table 2). Higher genetic similarity can be observed between species of genus Diadema and $E$. calamaris as they are members of the same family, Diadematidae. An average value of 9.85\% genetic distance was recorded among D. setosum and D. savignyi samples from Malaysian Borneo (Table 2) indicating certain degree of distinctions and also similarities which is congruent with Lessios (2001). Low number of samples involved in this study may lead to underestimation of the actual genetic variation among samples of Malaysian Borneo Diadema. Thus, the relationship between $D$. setosum and $D$. savignyi from Malaysian Borneo was conducted to clarify relationships among the two species. 
Table 2. Average genetic distance (\%) values based on 16S rRNA gene sequences analysis using Kimura Two Parameter Model (Kimura, 1980).

\begin{tabular}{lcccc}
\hline & $\begin{array}{c}\text { D. setosum } \\
(\mathrm{n}=8)\end{array}$ & $\begin{array}{c}\text { D. savignyi } \\
(\mathrm{n}=3)\end{array}$ & $\begin{array}{c}\text { E. calamaris } \\
(\mathrm{n}=5)\end{array}$ & $\begin{array}{c}\text { T. gratilla } \\
(\mathrm{n}=4)\end{array}$ \\
\hline D. setosum & 0.45 & - & & \\
D. savignyi & 9.85 & 0.75 & - & \\
E. calamaris & 13.85 & 13.55 & 0.20 & - \\
T. gratilla & 31.50 & 32.30 & 33.0 & 2.3 \\
\hline
\end{tabular}

Phylogenetic analyses of Malaysian Borneo Diadematidae produced essentially the same trees topologies for MP (Figure 3), NJ (not shown), BA (Figure 4) and ML (not shown) which revealed a monophyly of the Malaysian Borneo Diadematidae (including E. calamaris as ingroup) with respect to the outgrop $T$. gratilla (family Toxopneustidae) with bootstrap values of $100 \%$ (MP), $100 \%$ (NJ), $100 \%$ (ML) and bayesian posterior probability value of 1.00. Moreover, E. calamaris were later diverged from the Diadematidae forming Clade III (Figure 3 and Figure 4), excluding the Diadema species into another clade, with strong support as the bootstrap values are $100 \%$ (MP), 100\% (NJ), 96\% (ML) whereas the Bayesian Posterior Probability (BPP) value is 1.00 .

Monophyly of Malaysian Borneo Diadema was revealed with high bootstrap values of 99\% (MP), 94\% (NJ), 84\% (ML) and the BPP value of 98 , with respect to the outgroup $E$. calamaris and T. gratilla (Figure 3 and Figure 4). The monophyletic grouping of Malaysian Borneo Diadema was further divided into two distinct monophyletic clades comprised all $D$. setosum samples into Clade $\mathrm{I}$ and all $D$. savignyi samples into Clade II (Figure 3 and Figure 4).

Monophyletic grouping of D. setosum (Clade I) has strong support with high bootstrap values of $100 \%$ (MP), $100 \%$ (NJ), $80 \%$ (ML) and BPP value of 100. Similarly, monophyletic grouping of $D$. savignyi also recorded strong support with bootstrap values of $100 \%(\mathrm{MP}), 100 \%(\mathrm{NJ}), 100 \%$ (ML) and BPP value of 100 (Figure 3 and Figure 4), thus one may say both species are reciprocally monophyletic.

In this study, phylogenetic relationship of genus Diadema from Malaysian Borneo revealed that both $D$. setosum and $D$. savignyi have distinct genetic identity showing deep split between $D$. setosum and $D$. savignyi (Figure 3 and Figure 4) which would have been sufficient to reject the suggestion by Clark (1966) that these two species are subspecies. This finding is congruent with other studies conducted by Mortenson (1940), Lessios (2001) and Lessios et al. (2001) in which $D$. setosum and $D$. savignyi formed two distinct monophyletic clades.

Clark (1966) claimed that due to morphological similarities of species in genus Diadema, identification of each species was usually based on locality. However, identification based on locality for D. setosum and $D$. savignyi has been chaotic until Pearse (1998) established that D. savignyi populations extended from the central Pacific Ocean to the Indian Ocean, while D. setosum populations only limited to the continental margins. Incongruent with Clark (1966) and Pearse (1998) on the geographical distributions of $D$. setosum and $D$. savignyi, sample of $D$. setosum (M06, M07 and M10) and D. savignyi involved in this study were collected from the same location (Mantanani Island, Sabah; $\left.6^{\circ} 42.8^{\prime} \mathrm{N} 116^{\circ} 18.3^{\prime} \mathrm{E}\right)$ at the continental shelf of South China Sea suggesting that theory to identify species based on locality (Clark, 1966 ) and that $D$. setosum only existed at the continental margins (Pearse, 1998), should be nullified. In Malaysian Borneo, D. setosum and $D$. savignyi co-exist in the same area and have overlapping ranges, similar to the findings by Mortenson (1940) and Lessios et al. (2001) who reported that these two species were found to be overlapped at the western margins of the Pacific Ocean and at the Australian and African shores of the Indian Ocean.

Moreover, this study also supports the theory on D. setosum and $D$. savignyi as the sympatric species, based on their overlapping 
ranges; thus the theory that sea urchin undergo allopatric speciation by Mayr (1954) is no longer valid. Debates on the specific status of sympatric species $D$. setosum and $D$. savignyi have been documented by many researchers for example Mortenson (1940); Mayr (1954); Clark (1966); Pearse (1998); Adel and Khalid (2000); Lessios (2001); Lessios et al. (2001) and Coppard and Campbell (2006). Most studies agreed that $D$. savignyi was believed to be the result of $D$. setosum annual rhythm of active spawning activities and over certain period of time, the annual rhythm of active spawning had led to the formation of sympatric species D. savignyi (Adel \& Khalid, 2000).

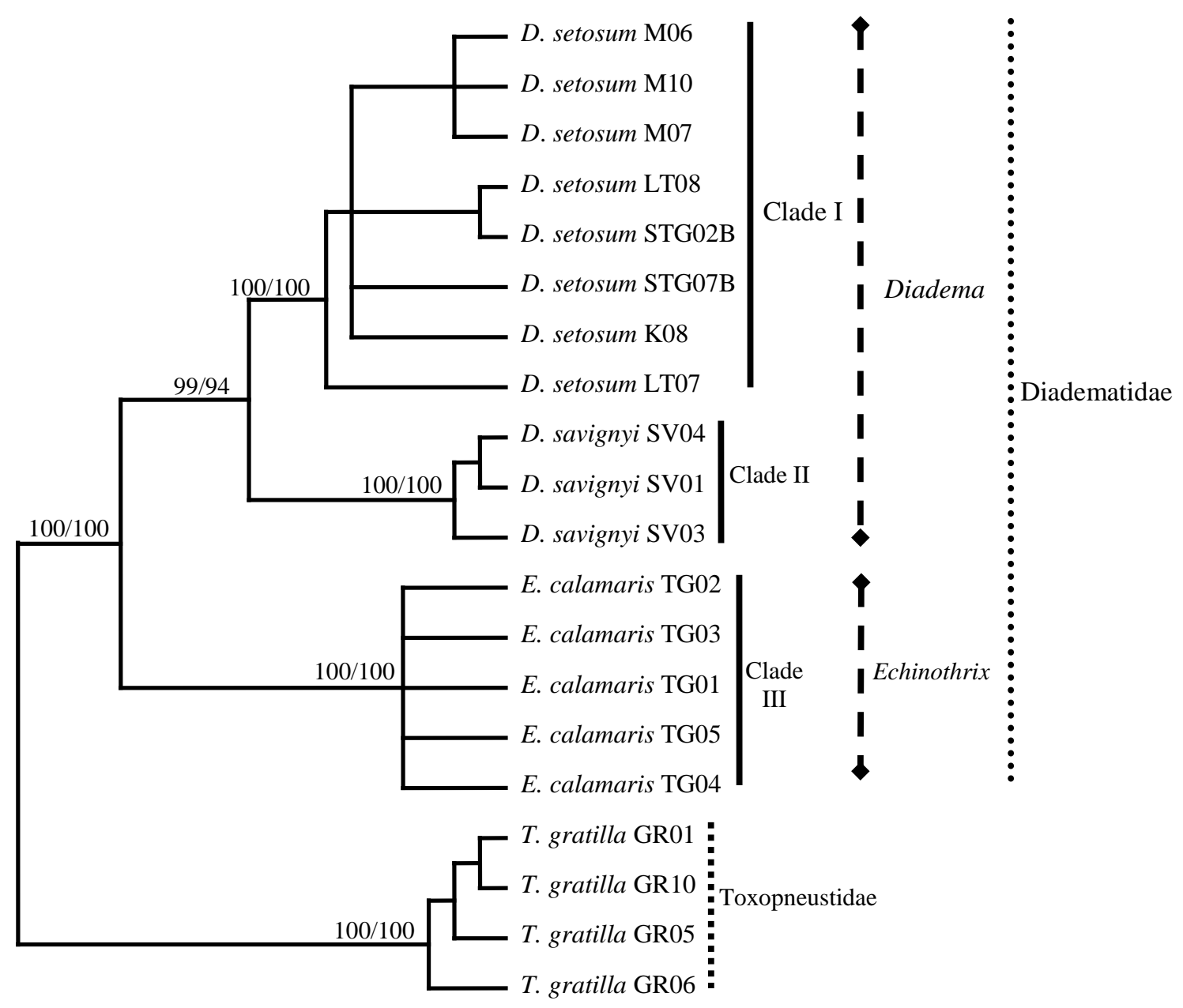

Figure 3. A maximum parsimony $50 \%$ majority rule consensus tree constructed of $16 \mathrm{~S}$ rRNA gene sequences of D. setosum, D. savignyi, E. calamaris with T. gratilla as the outgroup. Bootstrap values above $90 \%$ are indicated above branch and correspond to Maximum Parsimony and Neighbour joining, respectively. Tree length is 240 with consistency index $(\mathrm{CI})=0.9292$ and retention index $(\mathrm{RI})=0.9779$. 


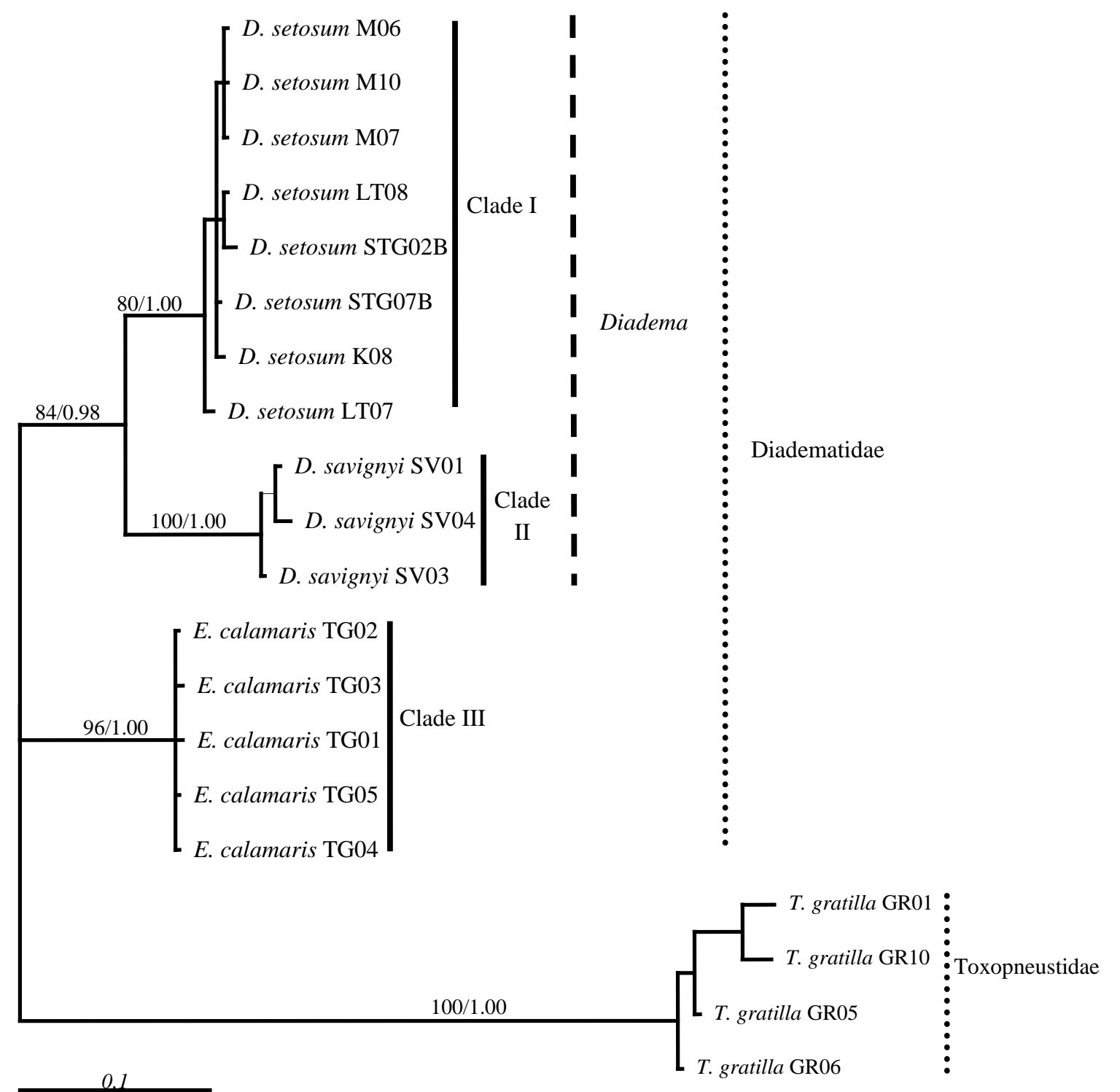

No. of substitution sites

Figure 4. Bayesian inference of the $50 \%$ majority rule consensus tree of $16 \mathrm{~S}$ rRNA gene sequences of $D$. setosum, D. savignyi and E. calamaris with T. gratilla as the outgroup. Bootstrap values of maximum likelihood and Bayesian posterior probabilities (BPPs) are accordingly indicated above the branch nodes.

\section{CONCLUSION}

In conclusion, based on 16S rRNA gene analysis, genus Diadema from Malaysian Borneo is monophyletic with respect to the outgroup, E. calamaris and T. gratilla. D. setosum and $D$. savignyi are reciprocally monophyletic, therefore hypothesis null is rejected. This study supports the theory on the sympatric species of D. setosum and $D$. savignyi based on their geographical distributions and overlapping ranges in Malaysian Borneo. Due to limited samples involved in this study, it is likely that the actual genetic variations within and among sea urchin species in Malaysian Borneo is not yet fully clarified, thus future studies should involve larger sample size collected from various localities. 


\section{ACKNOWLEDGEMENTS}

This project is partly funded by the Ministry of Higher Education research grant FRGS/07(02)/759/2010(45) awarded to Dr. Siti Akmar Khadijah Ab Rahim. Highest gratitude goes to Sarawak Forestry Cooperation for the permission to conduct this study and collection of sea urchin samples at Satang Island, NCCD.907.4.4(Jld.7)-62 and Park Permit N0.15/2012. Appreciation goes to Sabah Fisheries Department for the permission and cooperation on samples collection around Sabah coastal waters. Lastly, thanks to UNIMAS for kindly providing the transportation and other research facilities.

\section{REFERENCES}

Adel, H.A. \& Khalid, P.L. (2000). Reproductive cycles of Diadema setosum and Echinometra mathaei (Echinoidea: Echinodermata) from Kuwait (Northern Arabian Gulf). Bulletin of Marine Science, 67(2): 845-856.

Clark, A.M. (1966). Echinoderms from the Red Sea, Part 2. Bulletin of Sea Fisheries Resources Israel, 41: 26-58.

Coppard, S.E. \& Campbell, A.C. (2006). Taxonomic significance of test morphology in the echinoid genera Diadema Gray, 1825 and Echinothrix Peters, $1853 \quad$ (Echinodermata). Zoosystema, 28: 93-112.

Doyle, J.J. \& Doyle, J.L. (1987). A rapid DNA isolation procedure from small quantities of fresh leaf tissue. Phytochemical Bulletin, 1: 11-15.

Huelsenbeck, J.P. \& Hillis, D.M. (1993). Success of phylogenetic methods in the four-taxon case. Systematic Biology, 42: 247-264.

Kimura, M. (1980). Kimura's two-parameter model of Models of DNA Evolution. In J. Felsenstein (Eds.), Inferring Phylogenies. Sunderland, Massachusetts: Sinauer Associates, Inc.

Leache, A.D. \& Reeder, T.W. (2002). Molecular systematics of the eastern fence lizard (Sceloporus undulatus): a comparison of parsimony, likelihood and bayesian approaches. Systematic Biology, 51: 44-68.
Lessios, H.A. (2001). Molecular phylogeny of Diadema: Systematic implications. In M. Barker (Eds.), Echinoderms 2000. Lisse: CRC Press. Pp 487-495.

Lessios, H.A. \& Pearse, J.S. (1996). Hybridization and introgression between Indo-Pacific species of Diadema. Marine Biology, 126: 715-723.

Lessios, H.A., Kessing, B.D., \& Pearse, J.S. (2001). Population structure and speciation in tropical seas: global phylogeography of the sea urchin Diadema. Evolution, 55: 955-975.

Mayr, E. (1954). Geographic speciation in tropical Echinoids. Evolution, 8: 1-18.

McCartney, M.A., Keller, G., \& Lessios, H.A. (2000). Dispersal barriers in tropical oceans and speciation in Atlantic and eastern Pacific sea urchins of the genus Echinometra. Molecular Ecology, 9: 13911400.

Mortenson, T. (1940). A monograph of the Echinoidea. III(i). Aulodonta. Denmark: Reitzel. Pp 369-379.

Palumbi, S.R. (1996). PCR and molecular systematic. In D. Hillis, C. Moritz, \& B. Mable (Eds.), Molecular Systematic, $2^{\text {nd }}$ edition. Sunderland: Sinauer Press.

Pearse, J.S. (1998). Distributions of Diadema savignyi and Diadema setosum in the tropical Pacific. In R. Mooi \& M. Telford (Eds.), Echinoderms: San Francisco. Rotterdam: Balkema. Pp 777-782.

Posada, D. \& Crandall, K.A. (1998). Modeltest: testing the model of DNA substitution. Bioinformatics, 14(9): 817818.

Rahim, S.A.K.A., \& Nurhassan, R. (2012). Edible sea urchin species in Sabah waters. Faculty of Resource Science and Technology Bulletin, 1: 2-3.

Rannala, B. \& Yang, Z. (1996). Probability distribution of molecular evolution trees: a new method of phylogenetic inference. Journal of Molecular Evolution, 43: 304311.

Ronquist, F. \& Huelsenback, J.P. (2003). MrBayes 3: Bayesian phylogenetic inference under mixed models. Version 3.0b4. Bioinformatics, 19: 1572-1574. 
Sponer, R., Deheyn, D., \& Roy, M.S. (2001). Large genetic distances within a population of Amphipholis squamata (Echinodermata: Ophiuroidea) do not support color varieties as sibling species. Marine Ecological Progress Series, 219: 169-175.

Stockley, B., Smith, A.B., Littlewood, D.T.J., Lessios, H.A., \& MacKenzie-dodds, J.A. (2005). Phylogenetic relationships of spatangoid sea urchins (Echinoidea): taxon sampling density and congruence between morphological and molecular estimates. Zoological Science, 34: 447-468.
Swofford, D.L. (2000). PAUP. Phylogenetic Analysis Using Parsimony. Version 4.0b10. Sunderland, Massachusetts: Sinauer Associates.

Thompson, J.D., Gibson, T.J., Plewniak, F., Jeanmougin, F., \& Higgins, D.G. (1997). The ClustalX Windows interface: flexible strategies for multiple sequence alignment aided by quality analysis tool. Nucleic Acids Research, 24: 4876-4882.

Yokota, Y., Matranga, V., \& Smolenicka, Z. (2002). The sea urchin: From basic biology to aquaculture. Netherlands: A.A Balkema Publication.

\section{APPENDIX}

Aligned partial of 16S rRNA of mitochondrial DNA (excluded sites with missing/ambiguous data and gaps) for Malaysian Borneo D. setosum and D. savignyi. Sequence differences are indicated with respect to the uppermost sequence dot (.) indicates base similarity and shaded colors indicate potential sites for species DNA barcoding.
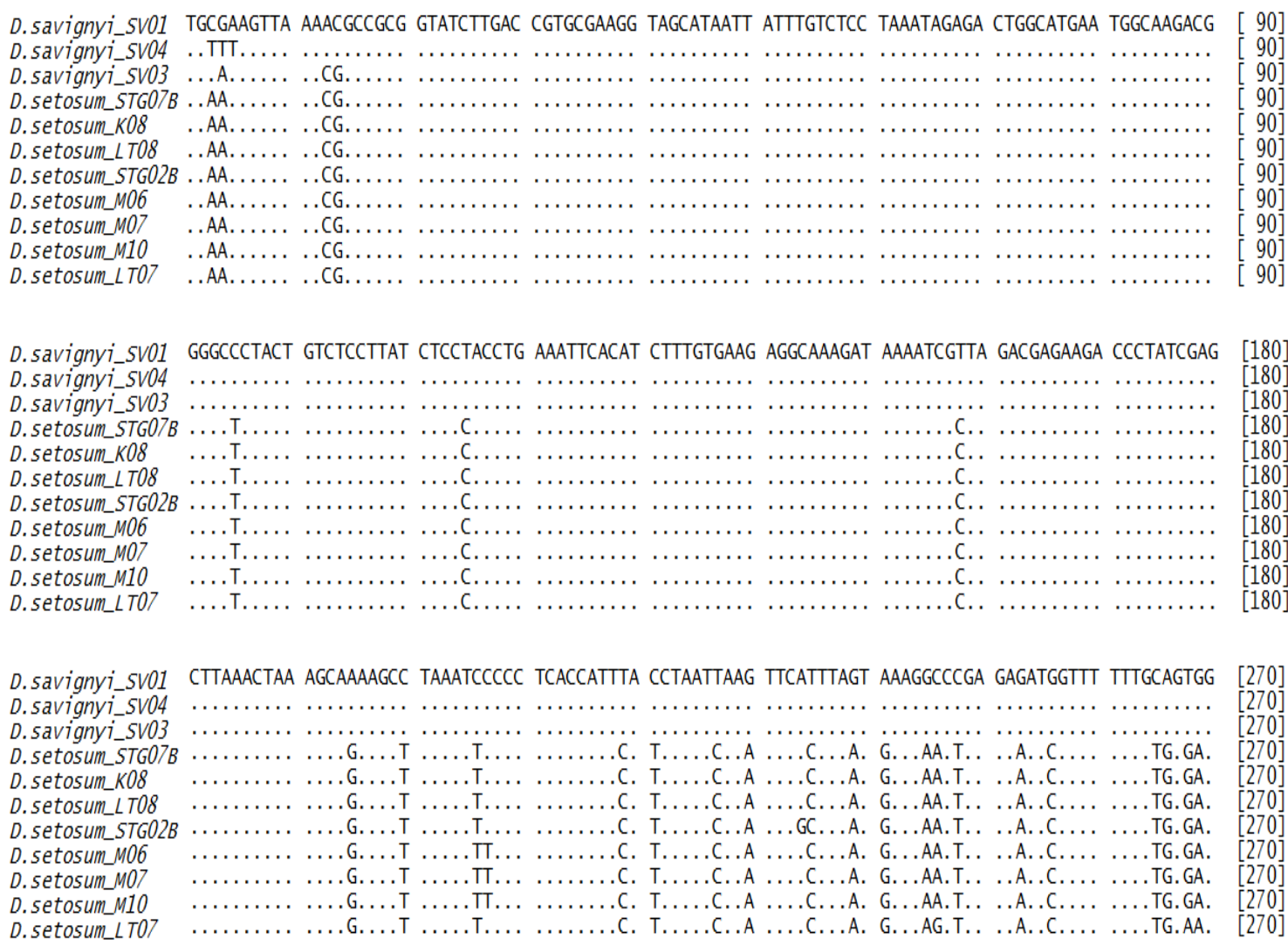
D.savignyi_SV01 TITTAGTTGG GGCAACTGCG GAGAAGAAGA CCCTCCGCTA CAATTTAAGT TTCTAGGAAG ACTGTCCTGG AACAGTACTG AAGAGTGATC D. Savignyi_SVO4

D. Savignyi_SVO3

D. Setosum_STGOTB

D. setosum_K08

D. Setosum_LTO8

D. setosum_STGO2B

D. setosum_M06

D. setosum MOT

D. setosum_M10

D. setosum_LTOT

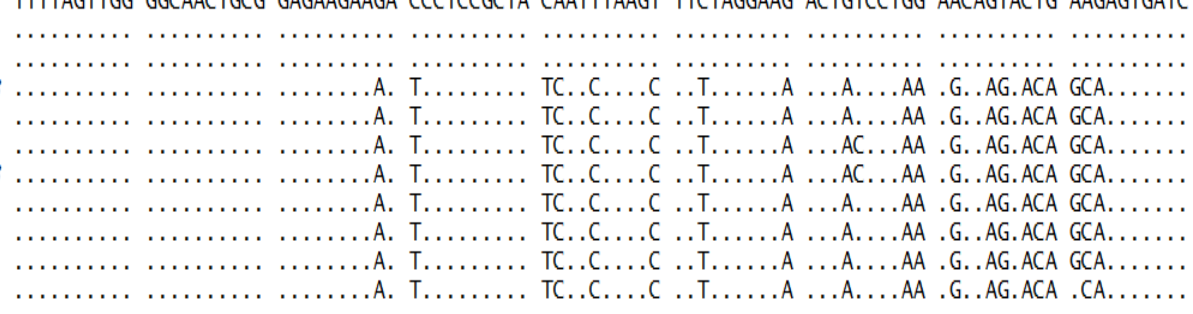

D.savignyi_sv01 CACTTAGGTG ATCAAAGGAA CAAGTTACCG TAGGGATAAC AGCGTAATCT TTTCCGAGAG TTCATATTGA CAAAAAGGTT TGCGACCTCG

D. savignyi_SVO4

D. Savignyi_SVO3

D. setosum_STGOTB

D. Setosum_K08

D. setosum_LTO8

D. setosum_STGO2B

D. setosum_M06

D. setosum_M07

D. setosum_M10

D. setosUm $L T O T$

...CCT.

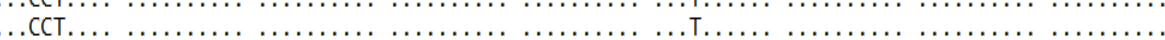

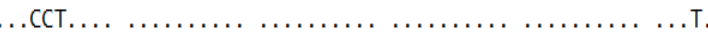

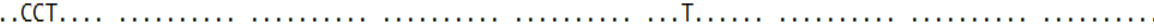

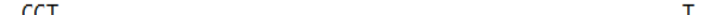

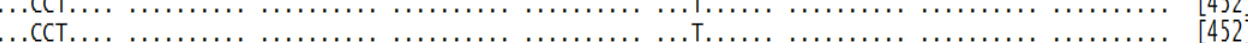

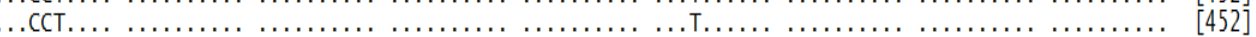

D.savignyi_SV01 ATGTTGGATC GGGACATCCT AATAGTGCAG AAGCTTTTAA GGGTTGGTCT GTTCGACCAT TAAAGTCCTA CGTGATCTGA GTTCAGACCG

D.savignyi_SVO4

D. savignyi_SVO3

D. Setosum_STGOTB

D. Setosum_K08

D. setosum_LTO8

D. setosum_STGO2B

D. setosum_M06

D. Setosum_MO7

D. setosum_M10

D. setosum_LTOT 